\title{
THE MAIN ASPECTS OF CHOOSING THE ENTERPRISES' OPERATING STRATEGY
}

\author{
Yuliia Karpenko \\ Odesa National Economic University, Ukraine \\ E-mail: juliakarpenko50@gmail.com
}

Anzhelika Pienova Odesa National Economic University, Ukraine

E-mail: a_penova2015@ukr.net

Dmytro Melnychuk Zhytomyr Polytechnic State University, Ukraine E-mail:melndp@ukr.net

Valentyna Kutsyk Lviv University of Trade and Economics, Ukraine E-mail: valentynakutsyk@gmail.com

Nataliya Nakonechna Lviv State University of Internal Affairs, Ukraine E-mail:nakonnat@gmail.com
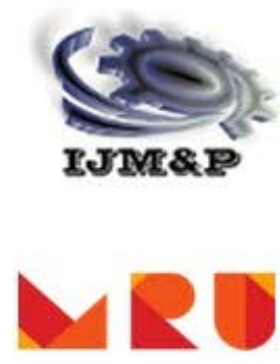

MYKOLAS ROMERIS UNIVERSITY

Sergiy Kalinichenko Kharkiv Petro Vasilenko National Technical University of Agriculture, Ukraine E-mail: kalinichenko.sergiy@gmail.com

Submission: 8/8/2021 Revision: 9/13/2021 Accept: 9/22/2021

\section{ABSTRACT}

Retail trade occupies an important place in the economy of Ukraine, ensuring the sale of manufactured goods to end consumers. For retailers, it is important to achieve timeliness and reliability of services to meet customer needs, which can be achieved through the formation of operational strategy. The purpose of the article is to form a methodological approach to the development of operational strategy of retail enterprises, which is based on the requirements of corporate strategy, selected in accordance with the stage of the life cycle of the industry. The development of this methodological approach was carried out on the basis of Hill's model and system approach. As a result, a logical scheme of the process of developing an operational strategy is presented, which is specified by the list of 
input and output information. In order to determine the stage of the life cycle of the market of retail services in Ukraine, the eponymous concept of Porter was applied and the analysis was carried out according to the criteria: consumers and their behaviour, sales costs, changes in services, the nature of competition, profitability and found that the retail services market is growing. The method of observation, comparative and analytical method was used for the analysis, the Herfindahl-Hirschman index (HHI) was calculated on the basis of the data of the largest retail trade enterprises of Ukraine. As a result, it was found that the market of retail services in Ukraine is growing. With this in mind, an operational strategy for Ukrainian retailers has been proposed, which should aim to ensure the flexibility and variability of the operating system. The defined general direction of the operational strategy will allow to establish the content of decisions on the choice of operational processes, as well as the infrastructure to support them.

Keywords: operational strategy; industry life cycle; retail enterprises of Ukraine; operational processes

\section{INTRODUCTION}

As an important component of Ukraine's economy, retail is one of the five most profitable industries and provides jobs for one in seven employees. High profits and low barriers to entry attract entrepreneurs, so the intensity of competition is growing every year. In such conditions, retailers are trying to achieve sustainable competitive advantages and are increasingly paying attention to operations as one of the sources of their formation.

In modern business conditions, one of the sources of competitive advantages of the enterprise may be operations. Successful implementation of operations that form the main operational function of the enterprise, as well as the latter's focus on achieving a certain operational priority, including low production costs, high quality and reliability of products, fast order fulfilment, high reliability of supply, ability to respond to changes in demand, flexibility and speed development of new products, increases the attractiveness of the enterprise compared to competitors.

An effective operational strategy is needed to form and maintain an enterprise's operational priority, but its development is often underestimated by management. In addition, scientific research does not provide recommendations for the choice of operational strategy 
taking into account the main aspects of the life of the trade enterprises, in particular the stage of the life cycle of the industry in which they work.

\section{LITERATURE REVIEW}

The content of operational strategies, classification approaches to them, the main stages of development, as well as the importance of operational strategies in the development of supply chain, coordination with financial, information and corporate strategies, the formation of operational strategies by enterprises of various fields of activity, set out in the scientific works of a number of scientists: Chapman and Gatewood (2017), Chase, Jacobs and Aquilano (2019), Wang and Huang (2019), Santa et al. (2020), Tarigan and Siagan (2021), Zatta et al. (2021), Ishfaq and Raja (2020) and Zhang, Zhang and Yue (2021).

One of the first scientists to pay attention to the formation of operational strategy was a famous scientist Hill (2005), who researched and outlined the main stages of its development.

The focus of the operational strategy to meet market needs is emphasized by Chapman et al. (2017). Scientists have examined in detail the main operational decisions for inventory management of the enterprise.

A comprehensive study of theoretical and practical aspects of operational management, the main types of operational decisions was conducted by scientists Chase, Jacobs, Aquilano (2019).

Researchers (Wang \& Huang, 2019) consider the importance of operational strategies and their integration with financial strategies in the development of a flexible supply chain with limited capital. The authors' work confirms that joint decisions of operational and financial strategies will be able to improve the flexibility of the supply chain and its performance in extreme situations.

The effect of coordination between operational, informational and corporate strategies has been studied in the scientific work of scientists (Santa et al., 2020). The analysis surveyed 138 large utility companies in the Australian electricity sector, and as a result used modelling using structural equations to establish the relationship between variables. As a result, the authors found that coordinating operational and information strategies can improve the efficiency of companies. 
The impact of strategic planning on the operating activities of the enterprise is analysed by the authors (Tarigan \& Siagan, 2021). Researchers note that procurement strategy and strategic partnership mediate the impact of strategic planning on operational results.

The scientific work of scientists (Zatta et al., 2021) is devoted to the study of the relationship between operational strategy and supply chain management. In particular, the study discusses the impact of relational resources on the performance of purchasing companies. The results show that operational skills are developed as a result of the interaction of relational resources shared in the supply chain.

Scientific sources also include research by the authors on the formation of operational strategies in the field of services. Thus, the means of solving operational problems in the field of trade are studied in the achievements of scientists (Ishfaq \& Raja, 2020). In particular, to address issues related to the inaccuracy of records regarding stocks in retail stores, scientists have proposed to conduct a technological audit of stocks and prove the effectiveness of this tool compared to others.

Researchers (Zhang; Zhang \& Yue, 2021) proposed an operational strategy for retail companies that are not exposed to risk, including coordinated pricing and replenishment of retail stocks in a competitive environment.

A review of scientific sources on the formation of operational strategy leads to the conclusion that, despite the existing scientific developments in this area, requires a detailed approach to developing operational strategy of the enterprise, taking into account the requirements of corporate strategy defined according to the life cycle stage.

The purpose of the article is to form a methodological approach to the development of operational strategy of the enterprise, which is based on the requirements of corporate strategy, selected in accordance with the stage of the life cycle of the industry.

\section{METHODOLOGY}

The authors used a systematic approach and the classical model of formation of T. Hill's operational strategy to determine the methodological aspects of developing the operational strategy of retail enterprises of Ukraine. This classical model emphasizes the subordination of corporate strategy. The concept of the life cycle of M. Porter's industry was used to determine the general features of the corporate strategy of retail enterprises in Ukraine. The study of the 
market of retail trade services in Ukraine was conducted using the method of observation and comparative analytical methods.

To establish the nature of competition in the retail market of Ukraine, the level of its concentration is determined by quantity (estimated by the Herfindahl-Hirschman market concentration index) and qualitative characteristics: the nature of services, market entry conditions, the presence of non-price competition. Fifteen of the largest retail trade enterprises in Ukraine were selected as the basis of the study.

Information for analysis was collected through our own research, publications by Ukrainian and foreign authors, websites of the enterprises and official statistics.

\section{RESULTS AND DISCUSSIONS}

\subsection{Result: a methodological approach to the development of operational strategy of the enterprise based on the corporate strategy selected in accordance with the stage of the life cycle of the industry is proposed}

One of the main theses that create the basis for the construction of the process of forming an operational strategy is its definition, provided by well-known scientists Chase, Jacobs and Aquilano (2019). Under the operational strategy is proposed to understand the development of general policies and plans for the use of enterprise resources aimed at effectively supporting its long-term strategy. Thus, scientists emphasize the relationship between operational and corporate strategy, and for service organizations emphasize the inseparability of operational strategy from corporate.

The subordination of the operational strategy to the overall strategy of enterprise development is emphasized by the authors Chapman et al. (2017). Scholars note the inevitability of conflicts between the goals of the enterprise and the goals of marketing, finance and production. In their opinion, the operational strategy should be balanced, i.e. to maintain customer service at the required level and ensure the rational use of enterprise resources. Scientists also distinguish five main levels in the system of production planning and control, the first of which is the development of a strategic plan, and the second - the formation of a production plan, i.e. once again emphasize the relationship between operational and corporate strategy.

The relationship between the basic strategic alternatives identified by the analysis of the internal and external environment of the enterprise, and functional strategies of the enterprise is emphasized in the source (Kotsko, 2016). 
DOI: 10.14807/ijmp.v12i6.1758

Thus, scientists are unanimous about the statement about the relationship and subordination of operational and enterprise development strategy.

Opinions of scientists are somewhat divided on the main stages of formation of the operational strategy of the enterprise. We have systematized the main stages of formation of operational strategy, presented in the scientific works of researchers (Kotsko, 2016; Bilyavsky, 2015; Pisareva, 2015; Chase, 2019), namely: the formation of general goals and performance indicators of the enterprise and their approval; analysis of the external environment of the enterprise; analysis of internal potential and formation of operational priorities of the enterprise; choice of operational strategy (construction of operational process; formation of infrastructure); implementation of operational strategy; evaluation and control of operational strategy.

In our opinion, it would be more expedient to take as a basis the classical model of formation of T. Hill's operational strategy (Hill, 2005). According to it, the stages of developing an operational strategy should include:

- $\quad$ setting corporate goals;

- definition of marketing strategy to achieve goals;

- analysis of opportunities to receive orders in comparison with competitors;

- development of the most appropriate processes for the production of products or services and the selection of optimal processes;

- definition of infrastructure to support selected operational processes.

T. Hill's model is sufficiently correlated with the procedure of harmonization of market requirements and capabilities of the operational function of the Platts-Gregory enterprise (Platts \& Gregory, 1990), which is carried out in three steps:

- study of threats and opportunities of the external environment. At this stage, the available operating resources of the enterprise and the achieved operational indicators are compared with market requirements;

- analysis of methods and capabilities of the enterprise to assess their ability to meet market requirements;

- consideration of alternatives and development of new operational strategies to address the shortcomings identified in the first two stages.

- Let's try to agree and detail the works of famous authors. 


\section{INDEPENDENT JOURNAL OF MANAGEMENT \& PRODUCTION (IJM\&P)}

http://www.ijmp.jor.br

v. 12, n. 6, Special Edition ISE, S\&P - November 2021

ISSN: 2236-269X

DOI: 10.14807/ijmp.v12i6.1758

The study of the content of the first stage of the proposed model allows us to emphasize that the process of forming an operational strategy is impossible without the development of corporate strategy. It is necessary to determine the stage of the life cycle of the industry to form a corporate strategy (Karpenko et al., 2021). Depending on the stage of the life cycle of the industry (introduction, growth, maturity or decline); certain changes take place in it, in particular in sales volumes, consumer behaviour, marketing activities, state of production, etc. The corporate strategy chosen in accordance with the stage of the life cycle will determine the characteristics of functional strategies, in particular operational.

At different stages of the life cycle of the industry, marketing tasks are different. Thus, at the stage of implementation, which is characterized by a small number of competitors and a low percentage of consumption of goods by buyers, the main task of marketing is to create initial demand for the product. At the stage of growth, when new players begin to enter the market, and the percentage of consumption of the product gradually reaches its maximum, the task of marketing is to adequately plan future demand and maximize market share. At the stage of growth, when new players begin to enter the market, and the percentage of consumption of the product gradually reaches its maximum, the task of marketing is adequate planning of longterm demand and maximizing market share. At the stage of recession, characterized by a decrease in sales dynamics, the task of marketing is to maintain the loyalty of existing customers.

Taking into account the above marketing tasks, which determine the essence of the marketing strategy, the operational priorities of the enterprise are set. They allow you to focus on those of them that favourably distinguish the company in a competitive environment. These priorities are formed as a result of the analysis of threats and opportunities of the external environment and tend to change over time. The implications of choosing each of the priorities should also be assessed.

Current operational priorities become mandatory for operations. To achieve them, it is necessary to assess the operational capabilities of the enterprise and compare them with market requirements and the capabilities of competitors. If the company's operational capabilities are sufficient to meet consumer demands, as well as exceed the capabilities of competitors, it receives the order, and management makes appropriate decisions about operational processes and infrastructure to support them. In case of insufficient operational capabilities, the management considers alternatives and takes measures to eliminate shortcomings. 
DOI: 10.14807/ijmp.v12i6.1758

In accordance with the objectives of the marketing strategy, the operational strategy at the stage of implementation should focus on the production of basic goods, trying to optimize production costs. At the stage of growth, it is aimed at ensuring the variability of production and output of improved goods of guaranteed quality, as well as the organization and improvement of service. The stage of maturity requires the operational strategy to create and maintain a sufficient variety of products (emergence of new models, design improvements, etc.), which will allow the company to maintain consumer interest in the company's products and maintain its market share. At the stage of recession, the operating strategy is aimed at ensuring the production of a narrow range of products under strict control of production costs.

Also at this stage, management may decide to implement certain types of operating strategy, classified according to the focus on achieving a certain operational priority or depending on the response of the operating system to changes in demand. Thus, the strategy of low costs, quality assurance and reliability of products, speed of order fulfilment, etc. can be implemented according to the selected operational priority. To establish the forms of the system's response to changes in demand, an operational strategy of matching demand can be chosen (characterized by production in strict accordance with market needs, maintenance of excess capacity or introduction of overtime work and involvement of temporary staff during peak hours); equalization of production (characterized by the same intensity of use of enterprise resources); subcontracting (characterized by the purchase of components from external sources or deliberate rejection of additional demand), a hybrid strategy.

The operational strategy formed in this way is approved by the management.

Thus, the process of forming an operational strategy can be graphically represented by a logical scheme (Figure 1).

\subsection{Result: the stage of the life cycle of the market of trade services is determined retail trade turnover of Ukraine; an operational strategy for trade enterprises is proposed}

In order to analyse the life cycle of the industry, we consider it appropriate to use the eponymous concept of Porter (2005).

The analysis will be conducted according to the criteria: consumers and their behaviour, sales costs, changes in services, profitability and the nature of competition. 
INDEPENDENT JOURNAL OF MANAGEMENT \& PRODUCTION (IJM\&P)

http://www.ijmp.jor.br

v. 12, n. 6, Special Edition ISE, S\&P - November 2021

ISSN: 2236-269X

DOI: 10.14807/ijmp.v12i6.1758

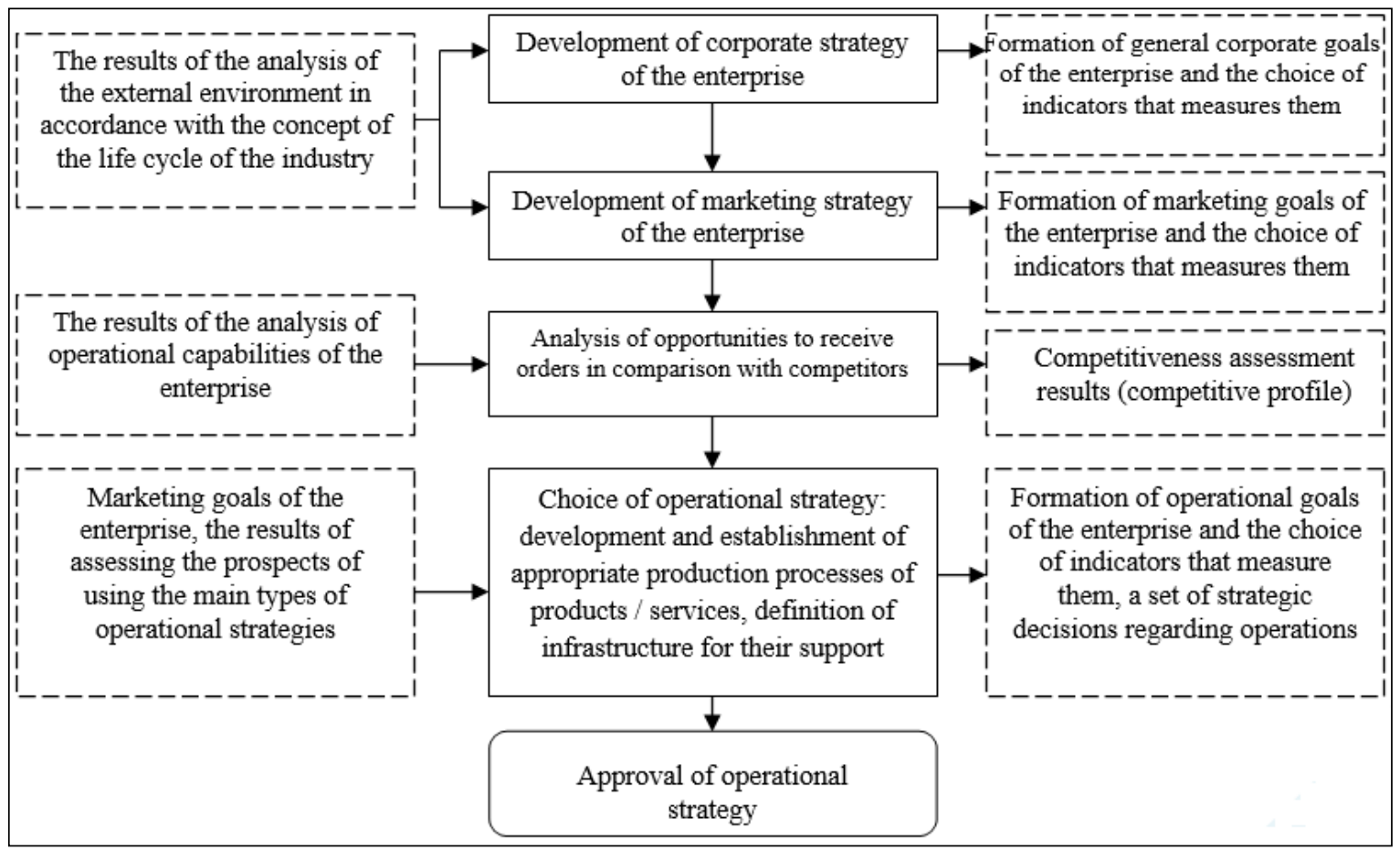

Figure 1: Logical diagram of the process of forming an operational strategy, refined by the list of input and output information

Consumers and their behaviour. Consumer behaviour can be investigated using the dynamics of retail trade turnover of Ukraine (Figure 2).

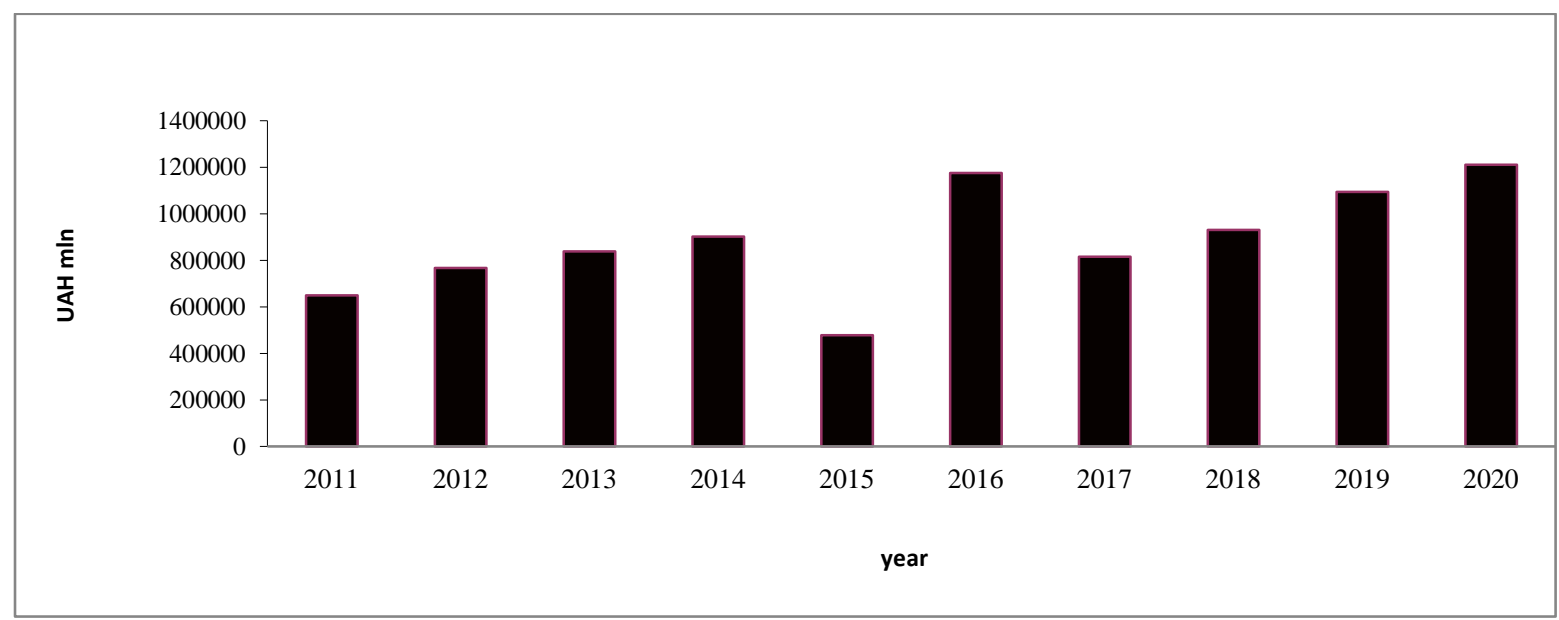

Figure 2: Dynamics of retail trade turnover in Ukraine, UAH million

Source: built by the authors according to the State Statistics Committee of Ukraine, 2021

It should be noted the tendency to increase the volume of goods sold. Thus, in 20112020 the volume of retail trade in general increased 1.9 times.

Selling expenses. According to a study of the financial statements of the fifteen largest retail trade enterprises in Ukraine, their sales costs increased by an average of 11\% Analysing the sales costs of 15 retail enterprises in Ukraine, we can conclude that the largest retail chains increased sales costs by an average of $19 \%$ (Table 1 ). 
INDEPENDENT JOURNAL OF MANAGEMENT \& PRODUCTION (IJM\&P)

http://www.ijmp.jor.br

v. 12, n. 6, Special Edition ISE, S\&P - November 2021

ISSN: 2236-269X

DOI: 10.14807/ijmp.v12i6.1758

Table 1: Sales costs of fifteen largest retail enterprises in Ukraine

\begin{tabular}{|c|c|c|c|c|}
\hline \multirow{2}{*}{ Name of Company } & \multicolumn{3}{|c|}{$\%$ to full cost } & \multirow{2}{*}{$\begin{array}{c}\text { Absolute } \\
\text { deviation } \\
2018 / 2020\end{array}$} \\
\hline & 2018 & 2019 & 2020 & \\
\hline LLC “ATB-MARKET” & 16.8 & 20.6 & 20.4 & 3.6 \\
\hline LLC “Silpo-Fud” & 25.5 & 27.3 & 32.9 & 7.4 \\
\hline LLC “FOR A" & 24.9 & 24.7 & 28.6 & 3.7 \\
\hline $\begin{array}{l}\text { LLC “Metro Cash \& Carry } \\
\text { Ukraine” }\end{array}$ & 11.5 & 11.8 & 15.3 & 3.8 \\
\hline LLC "RUSH” & 21 & 18.1 & 18.7 & -2.3 \\
\hline LLC “Omeha” & 14.4 & 13.6 & 14.1 & -0.3 \\
\hline Others & 18.7 & 19.2 & 21.6 & 2.9 \\
\hline
\end{tabular}

Source: Data from own research (2021)

Changes in services. The results of our own research on changes in the services of the fifteen largest retailers in Ukraine show that today there is an expansion and improvement of services of retail trade enterprises, namely the sale of goods through online stores; emergence of new delivery services; possibility to track the order; use of self-service cash registers; appearance of non-cash payment terminals at checkouts in stores with a payment function using a QR-code, which allow contactless payment for purchases; payment through mobile applications; use of social networks to advertise your own brand (table 2). All this indicates in favour of expanding the range of services of retail businesses.

Table 2: Information on the expansion of services of the fifteen largestretail trade enterprises of Ukraine

\begin{tabular}{|l|c|c|}
\hline \multirow{2}{*}{ Services } & \multicolumn{2}{l}{$\begin{array}{l}\text { Number of enterprises providing advanced } \\
\text { services }\end{array}$} \\
\cline { 2 - 3 } & absolute & $\begin{array}{c}\text { relative, in\% of the total } \\
\text { number of respondents }\end{array}$ \\
\hline Sale of goods through online stores & 13 & 86.6 \\
\hline New delivery services & 10 & 66.6 \\
\hline Ability to track orders & 7 & 46.6 \\
\hline Use of self-service checkouts & 7 & 46.6 \\
\hline $\begin{array}{l}\text { The emergence of non-cash payment terminals at checkouts } \\
\text { with the function of payment by QR-code }\end{array}$ & 15 & 100 \\
\hline Payment via mobile applications & 12 & 80 \\
\hline Advertising your own brand through social networks & 15 & 100 \\
\hline
\end{tabular}

Source: Data of own research (2021)

Profitability. To determine the level of profitability of retailers in Ukraine, it is advisable to analyse the dynamics of their financial results (Table 3).

Analysing the financial results of enterprises, we can say that in general the level of market profitability is quite high. This confirms the trend of increasing the number of profitable enterprises and reducing unprofitable throughout the study period. 
INDEPENDENT JOURNAL OF MANAGEMENT \& PRODUCTION (IJM\&P)

http://www.ijmp.jor.br

v. 12, n. 6, Special Edition ISE, S\&P - November 2021

ISSN: 2236-269X

DOI: 10.14807/ijmp.v12i6.1758

Table 3: Financial results до оподаткування retail trade enterprises of Ukraine

\begin{tabular}{|c|c|c|c|c|c|}
\hline \multirow[t]{2}{*}{ Years } & \multirow{2}{*}{$\begin{array}{l}\text { Financial result } \\
\text { before tax, UAH } \\
\text { million }\end{array}$} & \multicolumn{2}{|c|}{ Profitable enterprises } & \multicolumn{2}{|c|}{ Підприємства, які одержали збиток } \\
\hline & & $\begin{array}{c}\text { in\% to the total } \\
\text { number of enterprises }\end{array}$ & $\begin{array}{c}\text { financial } \\
\text { result, UAH } \\
\text { million }\end{array}$ & $\begin{array}{l}\text { in\% to the total number } \\
\text { of enterprises }\end{array}$ & $\begin{array}{c}\text { financial } \\
\text { result, UAH } \\
\text { million }\end{array}$ \\
\hline 2011 & 21591.5 & 66.7 & 48487.9 & 33.3 & 26896.4 \\
\hline 2012 & 9608.0 & 66.0 & 43877.8 & 34.0 & 34269.8 \\
\hline 2013 & -6047.6 & 67.2 & 36528.5 & 32.8 & 42576.0 \\
\hline 2014 & -128134.8 & 66.7 & 34360.9 & 33.3 & 162495.7 \\
\hline 2015 & -80564.3 & 76.1 & 56898.4 & 23.9 & 137462.7 \\
\hline 2016 & 7277.0 & 75.8 & 74418.1 & 24.2 & 67141.1 \\
\hline 2017 & 39296.3 & 75.2 & 89285.4 & 24.8 & 49989.1 \\
\hline 2018 & 86290.5 & 77.2 & 116641.6 & 22.8 & 30351.1 \\
\hline 2019 & 129113.3 & 77.1 & 159827.3 & 22.9 & 30714.0 \\
\hline 2020 & 41896.5 & 74.4 & 121242.9 & 25.6 & 79346.4 \\
\hline
\end{tabular}

Source: Research data (2021)

In 2011, the share of enterprises that made a profit was $66.7 \%$ of the total number of enterprises, and in 2020 it increased to 74,4 \%.

The nature of competition. According to our research, it should be noted that there is an increase in the number and expansion of the network of retail trade enterprises. Thus, in the first 6 months of 2020, 340 objects were opened in Ukraine by food trade networks. In addition, in the first half of 2020, the dynamics of opening new outlets exceeded the level of 2019 by $40 \%$. In general, following the results of the first half of 2020, the dynamics of the market reached the highest level in the last ten years in terms of the number of new outlets opened.

To determine whether there are structuring trends in the market, we consider it necessary by analysing the state of the retail services market in accordance with the quantitative and qualitative signs of market concentration.

The level of market concentration on a quantitative basis will be conducted using the Herfindahl-Hirschman market concentration index (NIS).

The Herfindahl-Hirschman index is calculated by the formula:

$$
\mathrm{HHI}=q_{1}^{2}+q_{2}^{2}+\ldots q_{n}^{2} \text {, }
$$

where $q$ is the market share of enterprises in total, \%;

$n$ is the number of market enterprises. $9-9$

The higher the value of the Herfindahl-Hirschman index, the higher the level of market concentration:

- the range from 800 to 1800 indicates a moderate level of market concentration;

- a range of less than 800 indicates low market concentration; 
INDEPENDENT JOURNAL OF MANAGEMENT \& PRODUCTION (IJM\&P)

http://www.ijmp.jor.br

v. 12, n. 6, Special Edition ISE, S\&P - November 2021

ISSN: 2236-269X

DOI: $10.14807 /$ ijmp.v12i6.1758

- a range greater than 1800 indicates that the market is highly concentrated.

The calculation of the Herfindahl-Hirschman index (HHI) for enterprises of the Ukrainian retail services market is presented in Table 4.

Table 4: Calculation of the Herfindahl-Hirschman Index (HHI) for Ukrainian retail services market enterprises

\begin{tabular}{|l|c|c|c|c|c|c|}
\hline \multirow{2}{*}{ Enterprise } & \multicolumn{2}{|c|}{ Market share (q), \% } & \multicolumn{3}{c|}{$q^{2}$} \\
\hline & 2018 & 2019 & 2020 & 2018 & 2019 & 2020 \\
\hline LLC “ATB-MARKET” & 9.21 & 9,59 & 10.23 & 84.87 & 91.96 & 104.66 \\
\hline LLC “Silpo-Fud” & 6.13 & 5.98 & 5.32 & 37.54 & 35.79 & 28.29 \\
\hline LLC “Epicenter K” & 4.46 & 4.18 & 4.16 & 19.85 & 17.44 & 17.32 \\
\hline LLC “Metro Cash \& Carry Ukraine” & 1.87 & 1.81 & 1.77 & 3.50 & 3.27 & 3.14 \\
\hline LLC “FORA” & 1.24 & 1.30 & 1.35 & 1.54 & 1.70 & 1.83 \\
\hline LLC “Auchan Ukraine Hypermarke”t & 1.66 & 1.30 & 1.17 & 2.76 & 1.68 & 1.36 \\
\hline LLC “COMFI Trade” & 1.31 & 1.25 & 1.34 & 1.71 & 1.55 & 1.78 \\
\hline LLC “Foktsroth” & 1.31 & 1.20 & 1.18 & 1.72 & 1.43 & 1.40 \\
\hline PE “Eva” & 1.08 & 1.18 & 1.11 & 1.17 & 1.38 & 1.23 \\
\hline PE “Rozetka” & 0.92 & 1.11 & 1.49 & 0.84 & 1.24 & 2.22 \\
\hline PE “Varus” & 1.13 & 1.03 & 0.94 & 1.29 & 1.07 & 0.89 \\
\hline LLC “Kviza-Treyd” & 0.99 & 1.01 & 0.97 & 0.98 & 1.02 & 0.95 \\
\hline LLC “Novus Ukrayina” & 0.98 & 1.00 & 0.92 & 0.96 & 1.00 & 0.84 \\
\hline PE “Eldorado” & 1.04 & 0.88 & 0.94 & 1.09 & 0.78 & 0.89 \\
\hline LLC “Fozzi-Fud” & 0.87 & 0.79 & 0.73 & 0.77 & 0.63 & 0.53 \\
\hline Others & 65.80 & 66.39 & 66.38 & 0.0017 & 0.0016 & 0.0016 \\
\hline Total & 100 & 100 & 100 & 160.57 & 161.96 & 167.33 \\
\hline
\end{tabular}

Source: built by the authors for (Zaitsev, 2020; Vinnichuk, 2021)

The Herfindahl-Hirschman index of the retail services market is 160.57 in 2018, 161.96 in 2019 and 167.33 in 2020, which indicates a low market concentration.

In order to characterize the market of retail services and establish the type of market structure, we consider it necessary to analyse its qualitative characteristics: the nature of services, market conditions and non-price competition (Dikan et al., 2012).

The nature of products or services can be standardized (homogeneous), differentiated or unique. The nature of the provision of services in the retail market can be considered standardized, as the range of services to meet the needs of consumers of most retail businesses. Thus, today retail enterprises provide pre-sales services (accepting orders, consulting and informing consumers, the ability to make online orders, organizing traffic to stores, etc.) and after-sales service (delivery of goods, packaging, lending, etc.). At the same time, according to the results of their own study of the activities of the fifteen largest retail enterprises in Ukraine, they are characterized by some expansion of the range of services, i.e. there is a tendency to differentiate.

We have identified the following barriers to entering the retail services market: 
- Cost advantage due to longer operation of enterprises in the market. The advantages of retailers already operating in the market include the availability of reliable suppliers, a high level of staff skills, customer loyalty.

- Tendency to product differentiation (services). Expanding the range of services, providing unique services among competitors.

- State regulation, which includes obtaining licenses to trade in certain categories of goods.

In general, the identified barriers to market entry can be described as minimal.

In the market of retail trade services of Ukraine there is non-price competition, which is presented in the form of creation and distribution of own trademarks (private label). The most famous brands among retail chains are "Svoia linia”, "Vesela ferma”, "Dobryi kuhar" (LLC “ATB-MARKET”); “Semerka”, “Saturday”, “Ukrainian Star” (LLC “Tavria-B”); “Aro”, "Fine Food” (Metro Cash \& Carry Ukraine LLC); "Vyhoda”, "Varto” (PE “Varus”) and others.

In accordance with the identified quantitative and qualitative characteristics of the market, as well as typical market models (Dikan et al., 2012; Okrepky and Mygal, 2016; Filon, 2016), we identified signs of market concentration of retail services (Table 5).

Table 5: Signs of concentration of the retail services market

\begin{tabular}{|c|c|c|c|c|c|}
\hline \multirow{2}{*}{$\begin{array}{l}\text { Signs of market } \\
\text { concentration }\end{array}$} & \multicolumn{4}{|c|}{ Market model } & \multirow{2}{*}{$\begin{array}{c}\text { Signs of market } \\
\text { concentration } \\
\text { of retail } \\
\text { services }\end{array}$} \\
\hline & $\begin{array}{c}\text { Pure } \\
\text { competition }\end{array}$ & $\begin{array}{l}\text { Monopolistic } \\
\text { competition }\end{array}$ & Oligopoly & Monopoly & \\
\hline $\begin{array}{l}\text { Quantitative } \\
\text { characteristic }\end{array}$ & $\begin{array}{l}\text { Low level of } \\
\text { concentration }\end{array}$ & $\begin{array}{l}\text { Moderate level } \\
\text { of } \\
\text { concentration }\end{array}$ & $\begin{array}{l}\text { High level of } \\
\text { concentration }\end{array}$ & $\begin{array}{l}\text { Highest level of } \\
\text { concentration }\end{array}$ & $\begin{array}{l}\text { Low level of } \\
\text { concentration }\end{array}$ \\
\hline $\begin{array}{c}\text { Herfindahl- } \\
\text { Hirschman } \\
\text { index } \\
\end{array}$ & $\mathrm{HHI}<800$ & $800<\mathrm{HHI}<1800$ & $\mathrm{HHI}>1800$ & $\mathrm{HHI}>1800$ & 167.33 \\
\hline \multicolumn{6}{|l|}{$\begin{array}{c}\text { Qualitative } \\
\text { features }\end{array}$} \\
\hline $\begin{array}{l}\text { The nature of } \\
\text { the provision of } \\
\text { services }\end{array}$ & Homogeneous & Differentiated & $\begin{array}{c}\text { Standardized or } \\
\text { differentiated }\end{array}$ & Unique & $\begin{array}{c}\text { Homogeneous } \\
\text { tendency to } \\
\text { differentiation }\end{array}$ \\
\hline $\begin{array}{c}\text { Terms of } \\
\text { market entry }\end{array}$ & $\begin{array}{l}\text { No or minimal } \\
\text { barriers to entry }\end{array}$ & $\begin{array}{c}\text { Low barriers to } \\
\text { entry }\end{array}$ & $\begin{array}{c}\text { Significant } \\
\text { barriers to entry }\end{array}$ & $\begin{array}{l}\text { High barriers to } \\
\text { entry }\end{array}$ & $\begin{array}{c}\text { Low barriers to } \\
\text { entry }\end{array}$ \\
\hline $\begin{array}{c}\text { Non-price } \\
\text { competition }\end{array}$ & Missing & $\begin{array}{l}\text { Considerable } \\
\text { attention is paid } \\
\text { to advertising } \\
\text { and brand } \\
\text { creation }\end{array}$ & $\begin{array}{c}\text { Providing } \\
\text { advertising that } \\
\text { emphasizes the } \\
\text { differentiation } \\
\text { of products } \\
\text { (services) }\end{array}$ & $\begin{array}{c}\text { Image } \\
\text { advertising, } \\
\text { advertising } \\
\text { communication } \\
\text { with public } \\
\text { organizations }\end{array}$ & $\begin{array}{l}\text { Considerable } \\
\text { attention is paid } \\
\text { to advertising } \\
\text { and brand } \\
\text { creation }\end{array}$ \\
\hline
\end{tabular}

Source: Developed by the authors based on (Dikan et al., 2012; Okrepky \& Mygal, 2016; Filon, 2016) 
INDEPENDENT JOURNAL OF MANAGEMENT \& PRODUCTION (IJM\&P)

http://www.ijmp.jor.br

v. 12, n. 6, Special Edition ISE, S\&P - November 2021

ISSN: 2236-269X

DOI: 10.14807/ijmp.v12i6.1758

As a result, it can be noted that the market of retail services in terms of quantitative and most qualitative characteristics, namely the nature of services and market conditions, should be attributed to the market with pure competition. There are many companies in the market; there are no trends towards structuring.

In general, we found an increase in retail sales, increased sales costs of commercial enterprises, expanding the range of services of trade enterprises, increasing the number of competitors and increasing profitability, which indicates that the retail market is growing (Table 6).

Table 6: Life cycle analysis of the retail services market in Ukraine

\begin{tabular}{|c|c|c|c|c|c|}
\hline \multirow[b]{2}{*}{ Criteria } & \multicolumn{4}{|c|}{ Stages of the life cycle } & \multirow[b]{2}{*}{$\begin{array}{l}\text { Stages of the life } \\
\text { cycle of the retail } \\
\text { services market }\end{array}$} \\
\hline & $\begin{array}{l}\text { Entering the } \\
\text { market }\end{array}$ & Growth & $\begin{array}{c}\text { Maturity } \\
\text { Stability of the } \\
\text { range of goods / } \\
\text { services }\end{array}$ & Decline & \\
\hline $\begin{array}{l}\text { Consumers } \\
\text { and their } \\
\text { behaviour }\end{array}$ & $\begin{array}{l}\text { Passive } \\
\text { consumer } \\
\text { behaviour }\end{array}$ & $\begin{array}{l}\text { Increasing } \\
\text { consumption }\end{array}$ & $\begin{array}{l}\text { Saturation of the } \\
\text { market, the choice } \\
\text { among brands } \\
\text { becomes the rule }\end{array}$ & $\begin{array}{l}\text { Demanding } \\
\text { and legible } \\
\text { consumers }\end{array}$ & $\begin{array}{l}\text { Increasing } \\
\text { consumption }\end{array}$ \\
\hline $\begin{array}{l}\text { Selling } \\
\text { expenses }\end{array}$ & $\begin{array}{l}\text { Highest sales } \\
\text { costs }\end{array}$ & $\begin{array}{l}\text { Some increase in } \\
\text { sales costs, but they } \\
\text { are lower than at the } \\
\text { market entry stage }\end{array}$ & Reduce sales costs & $\begin{array}{l}\text { Low sales } \\
\text { costs }\end{array}$ & Rising sales costs \\
\hline $\begin{array}{l}\text { Changes in } \\
\text { goods / } \\
\text { services } \\
\end{array}$ & $\begin{array}{c}\text { Narrow range } \\
\text { of goods / } \\
\text { services }\end{array}$ & $\begin{array}{l}\text { Expanding the range } \\
\text { of goods / services }\end{array}$ & $\begin{array}{l}\text { Stability of the } \\
\text { range of goods / } \\
\text { services }\end{array}$ & $\begin{array}{l}\text { Narrowing the } \\
\text { range of goods } \\
\text { / services }\end{array}$ & $\begin{array}{c}\text { Expanding the } \\
\text { range of goods / } \\
\text { services } \\
\end{array}$ \\
\hline $\begin{array}{c}\text { The nature of } \\
\text { competition }\end{array}$ & $\begin{array}{c}\text { A small } \\
\text { number of } \\
\text { competitors }\end{array}$ & $\begin{array}{l}\text { A large number of } \\
\text { competitors }\end{array}$ & $\begin{array}{l}\text { Displacement from } \\
\text { the market }\end{array}$ & Exit the market & $\begin{array}{c}\text { A large number of } \\
\text { competitors }\end{array}$ \\
\hline Profitability & $\begin{array}{c}\text { Low } \\
\text { profitability, } \\
\text { high prices }\end{array}$ & $\begin{array}{l}\text { High level of } \\
\text { profitability }\end{array}$ & $\begin{array}{l}\text { Decrease in prices, } \\
\text { level of profitability }\end{array}$ & $\begin{array}{l}\text { Lowest prices } \\
\text { and } \\
\text { profitability }\end{array}$ & $\begin{array}{l}\text { High level of } \\
\text { profitability }\end{array}$ \\
\hline
\end{tabular}

Source: Developed by the authors based on (Porter, 2005)

The next stage in the formation of operational strategy is the development of marketing strategy, which for retailers, given the stage of the life cycle of the industry, should focus on adequate planning of long-term demand and market share by developing the sales network, expanding the range, developing its own brand and others.

Based on the analysis of the company's operational capabilities retail trade and their comparison of the latter with market requirements and competitors' capabilities, an operating system for changes in consumer demand, support for the production of quality goods under its own brand, improving service. Decisions on the choice of operational processes, as well as the infrastructure to support them, which will achieve certain operational priorities, may include decisions on product range management (in particular, increasing products under its own 
DOI: 10.14807/ijmp.v12i6.1758

brand), on the organization of supply of goods and substantiation of the inventory management system, the introduction of new services and improvement of the maintenance process.

\section{CONCLUSIONS AND RECOMMENDATIONS}

The conducted study allows us to draw conclusions:

1) Defined in accordance with the concept of the same name, the life cycle stage of the industry establishes the main features of the corporate strategy of the enterprise, which in turn regulates the content of marketing and operational strategies. According to the tasks of the marketing strategy, the operational strategy at the stage of implementation should focus on the production of basic goods and optimization of production costs, at the stage of growth - to ensure variability of production and yield of improved product quality, as well as organization and improvement of service. The operational strategy at the stage of maturity should be aimed at creating and maintaining a sufficient variety of products, at the stage of decline - to ensure the production of a narrow range of products under strict control of production costs. The practical significance of the methodological approach developed by the authors to the formation of the operational strategy of enterprises is to create a basis for establishing its characteristics. The latter provide an opportunity to identify the main types of management decisions made within the operational strategy.

2) According to the results of the life cycle analysis of the Ukrainian retail services market by criteria: consumers and their behaviour, sales costs, changes in services, the nature of competition and profitability, it was found that it is growing. With this in mind, the operating strategy of retailers should be aimed at ensuring flexibility and variability of the operating system by improving the management of the product range, reliable organization of supply of goods and substantiation of the inventory management system, the introduction of new services and improvement of the maintenance process.

\section{REFERENCES}

Balabash, O., Ilin, V., Poprozman, N., Kuznetsova, I., Shushpanov, D., \& Slavina, N. (2021). Content Strategy in Management of Communications. Independent Journal of

Management \& Production, 12(3), s232-s242. DOI:

https://doi.org/10.14807/ijmp.v12i3.1538.

Bickauske, D., Simanaviciene, Z., Jakubavicius, A., Vilys, M., \& Mykhalchyshyna, L. (2020). Analysis and Perspectives of the Level of Enterprises Digitalization (Lithuanian Manufacturing Sector Case). Independent Journal of Management \& Production, 11(9), 2291-2307. 
INDEPENDENT JOURNAL OF MANAGEMENT \& PRODUCTION (IJM\&P)

http://www.ijmp.jor.br

v. 12, n. 6, Special Edition ISE, S\&P - November 2021

ISSN: 2236-269X

DOI: 10.14807/ijmp.v12i6.1758

Bilyavsky, V. (2015). Technology of implementation of operational strategy of the organization. Collection of scientific works DETUT. Economics and Management Series, 34, 233-241.

Chapman, S. N., Arnold, J. R. T., Gatewood, A. K., \& Clive, L. M. (2017). Introduction to Materials Management (8th ed.). Boston: Pearson Education.

Chase, R. B., Jacobs, R. F., \& Akvilano, N. J. (2019). Production and operational management, Moscow: Publishing house «Dialectic».

Dikan, V. L., Borovik, J. T., \& Polyakova, O. M. (2012). Ensuring the competitiveness of enterprises. Kharkiv: UkrDAZT.

Filon M. M. (2016). Research of the economic essence of competition, its influence on the formation of the market structure in the national economy. Scientific Bulletin of Kherson State University. Economic Sciences, 17(4), 40-43. Retrieved from:

http://nbuv.gov.ua/UJRN/Nvkhdu_en_2016_17\%284\%29_11

Grinenko, Ju., Melnychuk, D., Mykhalchyshyna, L., Belei, S., \& Yevtushenko, N. (2021). Improving Transfer Pricing in Ukraine using American Experience. Independent Journal of Management \& Production, 12(3), 205-231. DOI: https://doi.org/10.14807/ijmp.v12i3.1524

Hill, T. (2005). Operations management (2nd ed.). New York, NY: Palgrave Macmillan.

Ishfaq, R., \& Raja, U. (2020). Empirical evaluation of IRI mitigation strategies in retail stores. Journal of the Operational Research Society, 71, 1972-1985. DOI: 10.1080/01605682.2019.1640592.

Karpenko, L., Chunytska, I., Oliinyk, N., Poprozman, N., \& Bezkorovaina, O. (2020). Consideration of Risk Factors in Corporate Property Portfolio Management. Journal of Risk and Financial Management, 13 (2), 299. DOI: 10.3390/JRFM13120299.

Karpenko, Y., Kuznetsova, I., Chykurova, A., Matveyeva, M., Hridin, O., \& Nakonechna, K. (2021). Formation of the Enterprise Strategy based on the Industry Life Cycle. Independent Journal of Management \& Production, 12(3), 262-280. DOI:

https://doi.org/10.14807/ijmp.v12i3.1537

Kotsko, T. (2016). Formation of operational strategy of energy generating enterprises of Ukraine in the conditions of activation of threats of external environment. Economic Bulletin of the National Technical University of Ukraine "Kyiv Polytechnic Institute", 13, 283-289.

Kuznetsova I., Karpenko Yu., \& Vidomenko I. (2020). Technology of operational management in the activities of port elevators. Independent Journal of Management \& Production, 11(8), 762-782. DOI: dx.doi.org/10.14807/ijmp.v11i8.1203.

Lohosha, R., Mykhalchyshyna, L., Prylutskyi, A., Kubai, O. (2020). Institutionalization of the agrarian market in Ukraine and European economic community: genesis, evaluation and analysis. Independent Journal of Management \& Production, 11(8), 727-750.

DOI: 10.14807/IJMP.V11I8.1232

Okrepky, R. B., \& Mygal, O. F. (2016). Methodical aspects of using quantitative indicators of commodity market concentration and the degree of its monopolization. Ukrainian Journal of Applied Economics, 1(4), 81-88. Retrieved from:

http://dspace.wunu.edu.ua/bitstream/316497/16616/1/10.pdf.

Pisareva, N. V. (2015). Integration of operational management tools in the management system of agricultural enterprises, Abstract of the Dissertation, 20. 
INDEPENDENT JOURNAL OF MANAGEMENT \& PRODUCTION (IJM\&P)

http://www.ijmp.jor.br

v. 12, n. 6, Special Edition ISE, S\&P - November 2021

ISSN: 2236-269X

DOI: 10.14807/ijmp.v12i6.1758

Platts, K. W., \& Gregory, M. J. (1990). Manufacturing Audit in the process of Strategy Formulation. International Journal of Operations and Production Management, 10(9), 526.

Porter, E. M. (2005). Competitive Strategy: A Methodology for Analyzing Industries and Competitors. Tr. from English Moscow: Alpina Business Books, 454.

Rudnichenko, Y., Dzhereliuk, I., Mykhalchyshyna, L., Savina, S., Pokotylova, V., \& Havlovska, N. (2020). Safe Interaction Management of State Institutions and Business Entities Based on the Concepts of Evolutionary Economics: Modeling and Scenario Forecasting of Processes. TEM Journal. Technology, Education, Management, Informatics, 2, 233-241.

Santa, R. A., Acosta, A., Borrero, S., \& Scavarda, A. (2020). Corporate, operational, and information systems strategies: Alignment and firm performance. Estudios Gerenciales, 157, 454-464. DOI: 10.18046/j.estger.2020.157.3749

State Statistics Committee of Ukraine (2021). Unified State Register of Enterprises and Organizations of Ukraine. Available: http://www.ukrstat.gov.ua/.

Tarigan, Z. J. H., \& Siagan, H. (2021). The effects of strategic planning, purchasing strategy and strategic partnership on operational performance. Uncertain Supply Chain Management, 2, 363-372. DOI: 10.5267/j.uscm.2021.2.006.

Vinnichuk, Y. (2021). 200 largest companies of Ukraine in 2020. Business Censor. Available at: https://biz.censor.net/resonance/3268870/200_nayiblshih_kompanyi_ukrani_2020_roku Wang, M., \& Huang, A. (2019). The design of a flexible capital-constrained global supply chain by integrating operational and financial strategies. Omega-international Journal of Management Science, 58, 40-62. DOI: 10.1016/j.omega.2018.11.016.

Zaitsev, I. (2020). Top 200: rating of Ukrainian retailers for income, profit or loss. Retailers Association. Retrieved from: https://rau.ua/novyni/top-200-2/

Zalizko, V. D., Kanan, S. H., \& Poprozman, N. V. (2018). Economic and Financial Security of Azerbaijan in the Context of Institutional Convergations. Financial and Credit ActivityProblems of Theory and Practice, 2(25), 278-287. DOI: 10.18371/FCAPTP.V2I25.136867.

Zatta, F. N., Filho, E. T., Freitas, R. R., Goncalves, W., Oliveira, R. R., Segura, L. C., Formigoni, H., \& Schirrmeister, R. (2021). Operational competencies rooted in recourche theory: operations strategy and supply chain performance. Independent Journal of Management \& Production, 12, 756-779. DOI: 10.14807/ijmp.v12i2.1161.

Zhang, Z., Zhang, S. T., \& Yue, M. S. (2021). Joint pricing and replenishment policies for risk-averse retailers under duopolistic competition. Managerial and Decision Economics. DOI: $10.1002 /$ mde.3350. 